\title{
Vietnamese Learners' Reactions to Content and Language Integrated Learning Programs at a public university
}

\author{
Phuong-Bao-Tran Nguyen ${ }^{\# 1}$ \\ ${ }^{\# 1}$ School of Foreign Languages, Can Tho University, Vietnam \\ Department of Linguistics, KU University, Belgium
}

\begin{abstract}
One of the important goals of Vietnamese tertiary education is the acquisition of CLIL (Content-and-language integrated Learning) skills. In order to be successful on the national and international labor market, tertiary education students need to acquire both English as an international language skills and discipline-specific knowledge and skills at high functional levels. This paper reports study results using a quantitative method in which data were collected from a questionnaire from students in CLIL programs at a public university in Vietnam. The findings will provide additional relevant research evidence on student perceptions of CLIL instruction practices in Vietnam which could contribute to the sustainability and future development of dualfocused programs.
\end{abstract}

Keywords: Content and language integrated learning (CLIL), student perceptions, English proficiency, English anxiety, quantitative research.

\section{INTRODUCTION}

Learning English language plays a pivotal role in the internationalization of higher education since English is the most popular medium of instruction in education and its globalization movement. Adopting English language as the main tool for instructions enables institutions to develop their curriculum to attract foreign students and integrate into an intercultural and global domain. Tertiary educational programs have been accordingly adjusted to improve students' English language competence. As a result, an innovative methodology with dual focus of developing English language competence and subject knowledge, named as content and language integrated language learning (CLIL), has been coined in European and implemented in different international universities. The original aims of CLIL support learners to meet the expectations of our globalized world, in which they need to communicate effectively and confidently in intercultural working environments. Since CLIL programs were launched, there have been several major concerns for language educators, subject teachers, linguists, and researchers. In terms of educational perspective, a possible problem raised by Jensen is a loss of subject-content knowledge because learning cognition and process could be impaired in CLIL (Jensen et al., 2013). Recent studies have reported challenges and difficulties in implementing CLIL in Vietnam teaching contexts namely a shortage of English competence of teachers and learners, inadequate learning resources, content and language trade-offs, and inappropriate methodology ( $\mathrm{Vu} \&$ Burns, 2014). Therefore, solutions of improvement the qualitative and positive effects of the CLIL programs have been researched in different educational settings. Nevertheless, the issues relating to learners' attitudes and perceptions of CLIL implementation at tertiary educational levels in Asia have not received much attention in literature reviews.

This study investigates recent CLIL- integrated undergraduate programs at a regional university in Mekong Delta in the south of Vietnam. The current state-the-art nature of CLIL programs in Vietnamese contexts, and factors influencing learners' attitudes and its adaptation are analyzed in the paper. Using quantitative data from questionnaire-based collection, learners' reactions to the program could be described with research-based evidence hence proposing several implications to improve the quality of CLIL implementation in Vietnamese teaching context. Furthermore, based on these findings, recommendations to promote language learning skills, content learning skills, CLIL learning, and teaching skills are discussed. 
DOI: $\underline{10.51386 / 25815946 / \mathrm{ijsms}-\mathrm{v} 4 \mathrm{i} 5 \mathrm{p} 104}$

\section{LITERATURE REVIEW}

\section{Definitions of Content and Language Integrated Learning}

The term CLIL was defined by David Marsh in Finland to describe an innovative teaching approach to enhance learners' language and knowledge learning skills and an educational model for contexts where teachers and learners interact in the target language. It was originally introduced in Europe in the mid-1990s for the purpose of promoting EU citizens' mastery of a second language and a foreign language (Brown \& Bradford, 2017). The method provides flexibility to overly complex issues found in learning subject-matter knowledge in a foreign language thanks to its support to learners in developing their language communication skills in their working professional fields. In the literature, its conceptual framework has been extensively investigated in an attempt to achieve a better understanding of its implementation in a variety of teaching contexts.

There have been varied arguments and perspectives on the conceptualization of CLIL methodology in reformation of the approach from the past until now. Its advocates claim that its nature completely differs from language immersion and content-based instruction (Stryker \& Leaver, 1997 cited in Wolff, 2009). The idea of its proponents was to construct an "umbrella term" which encompasses different forms of integrating language learning into content learning and using the language as the medium of instruction (Genesee 1987 cited in Wolff, 2009;).

In a recent conference about "Transformation in Language Education", based on various updated international studies, Brown and Bradford (2017) distinguish CLIL from Content-based Instruction (CBI) and English-Medium Instruction (EMI) relying on a central emphasis on their teaching goals and the roles of a second language or foreign language (L2+). They define CLIL as "an educational approach that integrates language and content learning; planning, fostering and assessing both”. They also add that this methodology mainly depends on constructivism and socio-cultural notions of learning to offer students meaningful input and output in L2+ and to meaningfully engage them in their content learning.

Another CLIL definition by Coyle and her team (2011) demonstrates it as a dual-focused training program with attention to both subject-content and language acquisition (Coyle et al., 2010; Marsh \& Marsh, 2012). It aims to develop flexibly teaching contexts where thematic or subject content and foreign languages are integrated in beneficial ways to ensure learners' motivation to learn and use other languages in the future.

It can be understood that there is not a stable or fixed and typical pattern for CLIL (Coyle, 2013). A CLIL program can be designed and adjusted to be appropriate to its implemented educational contexts. Therefore, it is supposed to be more effective teaching than traditional language teaching in providing learners with intensive opportunities to reach further outcomes of improving language competences. To illustrate, CLIL proponents emphasize on its benefits to proficiency development of both the content subject and the language.

Coyle (2007)- a pioneer of the 4Cs Conceptual Framework of CLIL (4Cs) initiated it from a holistic perspective and offered a fundamental concept for a variety of CLIL adaptations, contributing to the present innovations of CLIL pedagogy (Coyle, 2007). The 4Cs Framework elaborates a notion of an effective teaching method in which learners acquire not only subject-matter knowledge but also language acquisition. There are four principal dimensions to constitute the 4Cs Conceptual Framework: subject-matter content; language for communication, language and subject-matter cognition, and culture. This model can be deployed in different levels of integration where learning (content and cognition), language learning (communication and cultures) and intercultural experiences are demonstrated on their interrelationship. The four components are considered to be intertwined in this framework of CLIL-education and CLIL-learning. The student needs to learn disciplinespecific content or concepts and new ways of reasoning and working in their typical discipline. These contents are thus embedded in a particular national and international context (culture), about which the students need to be able to communicate. Thus, to be successful in teaching CLIL, instructors require an ability to teach contents, cognition, culture and linguistic means in an integrated way, so as to support their students' learning. This belief is supported by the language acquisition theory that learners' learning progress is strongly connected with the 
DOI: $\underline{10.51386 / 25815946 / \mathrm{ijsms}-\mathrm{v} 4 \mathrm{i} 5 \mathrm{p} 104}$

development of language use, skills and subject-matter understanding (Chamot \& O'Malley, 1996; de Zarobe \& Zenotz, 2015). Furthermore, it is essential to reinforce intercultural awareness for learners so that they can use language effectively and confidently in intercultural working environments in the future. Therefore, the 4Cs framework is a practical teaching device for both teachers and practitioners to design CLIL activities and optimize the CLIL model (Coyle, 2007).

\section{CLIL in Vietnamese contexts}

Content and language integrated learning (CLIL) is not a new terminology in both language teaching and subject-content teaching in Vietnam. It has been applied in different levels of Vietnam educational system from primary to tertiary in which English and French as a medium of instruction (EMI) and (FMI). There used to be collaborations between Vietnamese Government and foreign Government, namely French, and English-speaking countries (Australia, the US, the UK) to pilot CLIL program in Vietnam with a primary goal to foster Vietnamese learners' language proficiency. In addition, these programs assisted to reform Vietnamese higher education system and reinforce cooperative and sustainable relationship with overseas institutions.

The CLIL project's aims are in line with the goals of the National Foreign Language Project (Project 2020) that intends to enable the young generation to possess a good command of a foreign language to confidently communicate, study and work in a multicultural environment, thus contributing to the economic development of the country (L. Nguyen \& Thuy, 2016). According to a vice minister of The Ministry of Education and Training (MOET), this CLIL project attempt to enhance English competence of both students and teachers. The program's outcomes would also offer them alternatives to access to advanced education for their further scientific capacity (T. B. N. Nguyen, 2019; Vu \& Burns, 2014).

According to Bain (2004), a good university lecturer requires certain characteristics: good knowledge of his/her subject content, high-quality publication list, scientific research skills (Bain, 2004). However, teaching staff in current universities in Vietnam are claimed to be inadequate and weak in both professional subjectcontent knowledge and linguistic competence. They are stated to be "bookish, poor in professional knowledge and skills, lag behind the development of the modern world, are too old and suffer from inertia to keep up with the changing world" (Quyen \& Yen, 2019) as mentioned by the ex-president of Vietnam National University. Statistical reports demonstrate that most academic staff are unable to write professional materials or journals in English and publish their research papers in high ranking journals (T. L. H. Nguyen, 2016).

Overall, there is a paucity of research into CLIL implementation at tertiary levels in Vietnamese context regarding the quality of teaching instructions, learning materials, learners' learning strategies and motivation. Therefore, it is an urgent demand to examine the effectiveness of current CLIL programs in encouraging students' use of English in their academic fields and increase their future employment competition ability.

\section{Foreign language anxiety in CLIL contexts}

Foreign language anxiety (FLA) is defined as a distinctive syndrome that includes three typical "symptoms", namely communication apprehension, fear of negative evaluation, and test anxiety (Gregersen \& Horwitz, 2002; Horwitz et al., 1986;). Communication apprehension refers to foreign language learners' inability to express themselves completely or to comprehend what other people state, causing frustration. Therefore, language experts claim learners' anxiety in their language learning process influences their academic results, motivation and attitudes (Gregersen \& Horwitz, 2002;MacIntyre \& Gardner, 1994; Chun et al., 2017). In CLIL contexts, while FLA is considered a critical element to success, its scarce evidence have been addressed. Besides, FLA could result in learners their unfavorable attitudes and avoidance in CLIL courses. Fear of negative evaluation in CLIL programs is related to learners' overconcerns about their academic and personal evaluations of their performance and competence of a foreign language (Gregersen \& Horwitz, 2002). "Test anxiety refers to a type of performance anxiety stemming from a fear of failure" (Horwitz et al., 1986, p.127). Hence, it is essential to explore that there may have negative influences of FLA in CLIL contexts on learners' subject academic performance since FLA could cause negative effects on learner's subject-content understanding and 
DOI: $\underline{10.51386 / 25815946 / \mathrm{ijsms}-\mathrm{v} 4 \mathrm{i} 5 \mathrm{p} 104}$

motivation. In addition, there should be future research in different contexts concentrating on relationships among learners' FLA, content learning achievement, as well as learning strategies which assist their low levels of foreign language proficiency in CLIL programs to achieve better subject-content results.

\section{Methodology}

The aim of the present study aimed to explore university students' perceptions of CLIL programs of three faculties namely Economics, Information and Technology and Engineering at a public university in Mekong Delta of Vietnam. Thus, the research aims to answer the following research questions:

(1) What levels of English proficiency have the students perceived within the CLIL programs?

(2) What levels of the students' English anxiety and confidence improved within the CLIL programs?

(3) What are student perceptions and attitudes toward the CLIL programs at the surveyed university?

To collect the data for analysis, a questionnaire was adapted and developed from Maiz-Areval \& Romero's (2013) and Soulioti's (2014). The questionnaire is divided into three primary sections that gain insights into (1) the students' education background, (2) their levels of English language proficiency and their English language anxiety, (4) their English language confidence, and (3) their attitudes toward content instructions and teaching activities in CLIL classrooms (see the Appendix).

The instrument was well constructed and consisted of a variety of question types (i.e., close-ended, openended, multiple-choice, and five-point Likert scale) to increase its validity and to obtain detailed responses from the participants. The questionnaire was initially designed in English and then translated into Vietnamese to ensure that the respondents comprehended the items thoroughly. The Vietnamese version was verified and approved by an expert - a Vice Dean of the Faculty of Foreign Languages at CTU. The questionnaire was administered to the participants on a random basis and their responses were analyzed using descriptive statistical measures.

To validate its reliability, results from the questionnaire were run to find out its Cronbach's Alpha coefficient $\alpha$ with SPSS Statistics 20 software (Statistical Package for the Social Science 20). According to Nunnally (1978), a research instrument is reliable if it obtains a reliability value of 0.70 or higher. With a Cronbach's alpha at .820 , it was confirmed that the questionnaire applied in the current study was reliable.

\section{RESULTS AND DISCUSSIONS}

\subsection{Students' English language proficiency level}

The results, as shown in Table 1, indicate over half (53\%) of the participants had not achieved certificates of English, while only $1.9 \%$ of the surveyed students obtained level C1. Furthermore, the most surprising result is the number of students with certificates of level B1 and B2 was not high (11.5\% and 32.5\% respectively). However, when the participants were asked to self-evaluate their current levels of English language proficiency, the proportion of the students' responses to B1-B2 levels is rather high which accounts for 53.8\% of B2-level and $26.9 \%$ of B1 level respectively. Interestingly, $3.8 \%$ of the students achieving the $\mathrm{C} 1$ level was observed in the data of the current level of English language proficiency.

Table 1

Description of CLIL learners' levels of English language proficiency Certificates of English Self-evaluation of the present levels of language proficiency English language proficiency

\begin{tabular}{llllll} 
& Frequency & Percent & Frequency & Percent & CEFR \\
$\begin{array}{lllll}\text { No } \\
\text { certificate }\end{array}$ & 56 & 53.8 & 12 & 11.5 & A1 \\
B1 & 12 & 11.5 & 4 & 3.8 & A2 \\
B2 & 34 & 32.7 & 28 & 26.9 & B1 \\
C1 & 2 & 1.9 & 56 & 53.8 & B2 \\
& & & 4 & 3.8 & C1 \\
\hline Total & 104 & 100.0 & 104 & 100.0 & Total \\
\hline
\end{tabular}


DOI: $\underline{10.51386 / 25815946 / \mathrm{ijsms}-\mathrm{v} 4 \mathrm{i} 5 \mathrm{p} 104}$

The results from investigating learners of the CLIL current programs at CTU reflect most students reached B1 and B2 levels of English language proficiency in CEFR. However, as asked about their English certificates, a large number of students did not attend in a high-quality examination of English language proficiency. This finding is consistent with the results from the previous study (T.T.T. \& P.H., 2019) which examined information on the English requirement eligible for entering CLIL programs of CTU. This analysis found evidence for challenges of CLIL implementation at CTU particularly and in Vietnam generally owing to learners' low levels of English language proficiency. This may be an important finding to understand the implementation of the English preparatory courses for students in CLIL programs at CTU because it probably eliminates 'subject-content loss', difficulties for both students and teachers in subject-content learning and teaching process of in a foreign language and improving learners' general English language competences. Therefore, specific, and appropriate teaching techniques and skills applied by CLIL instructors to compensate learners' gaps of English language proficiency and their varied levels should be concerned.

\subsection{Students' English anxiety and confidence improved within the CLIL programs Students' levels of English language anxiety}

Table 2 demonstrates information on the data analysis of the students' self-report of their English language anxiety during their CLIL learning program. In general, the results of data were rather negative and low $(M=2.79)$. The number of students who never felt quite confident in English speaking during their subjectcontent learning comprise of $17.3 \%$ of strong disagreements and $23.1 \%$ of disagreement. The percentage of students usually being frightened when they spoke English in their CLIL courses was $50 \%$ of strongly disagreed and disagreed answers. This mean score was lower than the average mean score of positive results of FLA in the CLIL programs $(M=2.43)$. There were few students worrying about their bad results of the CLIL courses (with $9.6 \%$ of agreed answers and $11.5 \%$ of strongly agreed answers). The most interesting is that the students who are more depressed and nervous in their subject course taught in English than in my other classes only accounted for $20.4 \%$ of the respondents.

Table 2

Descriptions of learners' English language anxiety in their CLIL program.

\begin{tabular}{|c|c|c|c|c|c|c|c|}
\hline Items & Mean & SD & $\begin{array}{l}\text { Strongl } \\
\mathrm{y} \\
\text { Disagre } \\
\mathrm{e} \\
(\%)\end{array}$ & $\begin{array}{l}\text { Disagre } \\
\mathrm{e} \\
(\%)\end{array}$ & $\begin{array}{l}\text { Neutra } \\
1 \\
(\%)\end{array}$ & $\begin{array}{l}\text { Agre } \\
\mathrm{e} \\
(\%)\end{array}$ & $\begin{array}{l}\text { Strongl } \\
\text { y agree } \\
(\%)\end{array}$ \\
\hline $\begin{array}{l}\text { I never feel quite confident in } \\
\text { myself when I am speaking in } \\
\text { English in my subject course. }\end{array}$ & 2.79 & 1.2 & 17.3 & 23.1 & 32.7 & 17.3 & 9.6 \\
\hline $\begin{array}{l}\text { I usually feel frightened when I } \\
\text { know that I am going to speak in } \\
\text { English in my subject course. }\end{array}$ & 2.42 & 1.1 & 25 & 25 & 34.6 & 13.5 & 1.9 \\
\hline $\begin{array}{l}\text { I feel frightened and stressful when I } \\
\text { do not understand what the } \\
\text { instructor is saying in English in my } \\
\text { CLIL courses. }\end{array}$ & 2.67 & 1.1 & 11.5 & 40.4 & 23.1 & 19.2 & 5.8 \\
\hline $\begin{array}{l}\text { I worry that my result will be poor } \\
\text { in my subject course. }\end{array}$ & 2.63 & 1.2 & 19.2 & 30.8 & 28.8 & 9.6 & 11.5 \\
\hline $\begin{array}{l}\text { I feel more depressed and nervous in } \\
\text { my subject course taught in English } \\
\text { class than in my other classes. }\end{array}$ & 1.94 & 1.0 & 38.5 & 42.3 & 9.6 & 5.8 & 3.8 \\
\hline
\end{tabular}

In terms of being confident in using English to learn CLIL courses, the results prove that overall students were not anxious about their English language use and skills within their lessons. They reported they performed rather confidently in their speaking skills during the courses. Furthermore, they hardly felt frightened to speak in English the content course and seldom worried about their results of the course.

\section{Students' levels of English language confidence}

Table 3 depicts general descriptions of students' self-evaluations of their improvement in terms of English language skills and knowledge of academic subjects. With regards to the development of learners' English language skills, there was $67.3 \%$ of the respondents and its mean score is relatively positive $(\mathrm{M}=3.94)$. 
DOI: $\underline{10.51386 / 25815946 / \mathrm{ijsms}-\mathrm{v} 4 \mathrm{i} 5 \mathrm{p} 104}$

Volume: 4 Issue: 5

The agreed and strongly agreed answers for developing learners' knowledge in other content courses accounted for nearly sixty percentage $(59.6 \%)$ with the positive mean score $(\mathrm{M}=3.94)$.

Table 3 learning

Description of Students' self-evaluations of their improvement in English language and subject-content

\begin{tabular}{lcccccc}
\hline & Mean & $\begin{array}{l}\text { Strongly } \\
\text { Disagree } \\
(\%)\end{array}$ & $\begin{array}{l}\text { Disagree } \\
(\%)\end{array}$ & $\begin{array}{l}\text { Neutral } \\
(\%)\end{array}$ & $\begin{array}{l}\text { Agree } \\
(\%)\end{array}$ & $\begin{array}{l}\text { Strongly } \\
\text { Agree } \\
(\%)\end{array}$ \\
\hline $\begin{array}{l}\text { CLIL improves my English } \\
\text { language skills }\end{array}$ & 3.94 & & 13.5 & 19.2 & 26.9 & 40.4 \\
\hline $\begin{array}{l}\text { CLIL develop my } \\
\text { knowledge in other content } \\
\text { courses. }\end{array}$ & 3.94 & & & 40.4 & 25 & 34.6 \\
& & & & & & \\
\end{tabular}

Despite the low percentages of teaching instructions in English, the findings of learners' self-evaluations of their improvement in English language and subject-content learning from this study are consistent with the benefits of CLIL in the previous research. The findings confirm the long-term beliefs that CLIL learners benefit from the programs in terms of language proficiency gains and this foreign language development is also beneficial alongside content learning enhancement (Bruton, 2013; Pavón Vázquez \& Ellison, 2013; Xanthou, 2011).

\subsection{Students' perceptions and attitudes toward the CLIL programs}

Table 4 demonstrates and compares the students' general attitudes towards the CLIL course. The participants indicated they had positive attitudes toward the CLIL courses. The number of students who were interested in and enjoyed the CLIL course accounted for $75 \%$ and $46.2 \%$ respectively. Almost half (40.3\%) of the students asserted CLIL courses as their favorite ones. Accordingly, most respondents chose not to postpone $(65.4 \%)$ and avoid CLIL courses with $34.6 \%$ strongly disagreed and $32.7 \%$ disagreed answers. Moreover, the mean scores of aspects regarding delay and avoidance of CLIL courses were low namely $2.25 \%$ and $2.09 \%$ respectively. In summary, numerous students had negative attitudes toward delay and avoidance of CLIL courses, which infers those students may satisfy with the CLIL implementation and they are willing to enroll further CLIL courses in the future.

Table 4

Descriptive data analysis' results of the students' attitudes toward CLIL courses

\begin{tabular}{|c|c|c|c|c|c|c|}
\hline Students' attitudes & Mean & $\begin{array}{l}\text { Strongly } \\
\text { Disagree } \\
(\%)\end{array}$ & $\begin{array}{l}\text { Disagree } \\
(\%)\end{array}$ & $\begin{array}{l}\text { Neutral } \\
(\%)\end{array}$ & $\begin{array}{l}\text { Agree } \\
(\%)\end{array}$ & $\begin{array}{l}\text { Strongly } \\
\text { Agree } \\
(\%)\end{array}$ \\
\hline $\begin{array}{l}\text { I am interested in CLIL } \\
\text { courses. }\end{array}$ & 3.88 & & 3.8 & 21.2 & 57.7 & 17.3 \\
\hline $\begin{array}{l}\text { CLIL courses are my } \\
\text { favorite classes. }\end{array}$ & 3.42 & & 9.6 & 50 & 28.8 & 11.5 \\
\hline I enjoy CLIL classes. & 3.55 & & 3.8 & 50 & 32.7 & 13.5 \\
\hline $\begin{array}{l}\text { I want to avoid CLIL } \\
\text { courses as much as } \\
\text { possible. }\end{array}$ & 2.25 & 23.1 & 42.3 & 25 & 5.8 & 3.8 \\
\hline $\begin{array}{l}\text { I want to delay taking } \\
\text { CLIL courses for as long } \\
\text { as possible. }\end{array}$ & 2.09 & 34.6 & 32.7 & 25 & 3.8 & 3.8 \\
\hline
\end{tabular}

From the positive results mentioned in the findings of the students' attitude toward the current CLIL programs and materials, it can be deduced most students may perceive preferences of the CLIL's materials applied at present since they could understand what CLIL courses benefit them in the progress of English language performance and academic knowledge acquisition. However, many students agreed that the materials were supposed not to promote their critical thinking and to develop English language acquisition. Thus, a greater 
DOI: $\underline{10.51386 / 25815946 / 1 j s m s-v 4 i 5 p 104}$

focus on designing appropriate CLIL materials could produce interesting findings that account more for the effective of the CLIL programs on development of knowledge of subject contents and language competences.

\section{CONCLUSIONS AND IMPLICATIONS}

The main purposes of this study were to explore the CLIL implementation at the three faculties of a public university. Particularly, it focused on the learners' self-evaluations of English language proficiency and their anxiety in the programs, and their perceptions of CLIL programs.

Regarding the CLIL implementation, these findings contribute to several alternatives to our understanding of presently applied for teaching instructions in English of the CLIL programs and provide a basis for the CLIL programs' benefits regarding developing their learners' English language skills and knowledge skills to study other subjects.

As concerns about students' attitudes and anxiety, the learners indicated positive evaluations. Although many students did not attend in an international and quality examination of English language proficiency, they self-reported their English language competences and learning academic subject skills were improved. The results agree with the previous research on outcomes of CLIL programs as a dual-focused training pedagogy of both language proficiency and content acquisition(Cenoz et al., 2014; McDougald, 2015). Additionally, although the enrollment eligibility for the CLIL programs at the surveyed public university do not require the students to perceive high qualified certificates of English language proficiency, the large majority of students generally were confident in speaking English to express their thoughts and academic purposes after the programs.

In terms of pedagogical implications to achieve successful CLIL programs, it is essential for stakeholders to consider crucial elements namely learners' levels of English language proficiency and anxiety in learning subject-content knowledge in English, their reactions to instructors' CLIL teaching competences and the learning materials. CLIL learners' English language proficiency could influence on their levels of English language anxiety, confidence of using English and comprehension of subject contents. As the learners are confident in using English in their CLIL classrooms, they will be engaged in their learning and ready to interact with other peers and teachers to acquire and perform the new knowledge. Once their English language anxiety about comprehension of difficult knowledge of subject contents and English language barriers are reduced, their motivation in learning academic subjects can be increased. It is additionally more important for CLIL teachers and instructors to be aware of their teaching content and English language competence in the programs. Thus, attending a training course to improve CLIL teaching skills is extremely indispensable to obtain the effective programs.

\section{About the authors}

Phuong Bao Tran Nguyen is a PhD student at KU Leuven, Department of Linguistics. She is also working as a lecturer of English at Can Tho University's School of Foreign Languages. Her main research interests include CLIL, EFL pedagogy, and blended learning in TESOL.

\section{References}

[1] Bain, K. (2004). What the Best College Teachers Do. In The Journal of Higher Education. Harvard University Press.

[2] Bruton, A. (2013). CLIL: Some of the reasons why... and why not. System, 41(3), 587-597. https://doi.org/10.1016/j.system.2013.07.001

[3] Cenoz, J., Genesee, F., \& Gorter, D. (2014). Critical analysis of CLIL: Taking stock and looking forward. Applied Linguistics, 35(3), 243-262. https://doi.org/10.1093/applin/amt011

[4] Chamot, A. U., \& O’Malley, J. M. (1996). The cognitive academic language learning approach: A model for linguistically diverse classrooms. Elementary School Journal, 96(3), 270-273. https://doi.org/10.1086/461827

[5] Cheng, R., \& Erben, A. (2012). Language Anxiety: Experiences of Chinese Graduate Students at U.S. Higher Institutions. Journal of Studies in International Education, 16(5), 477-497. https://doi.org/10.1177/1028315311421841

[6] Chun, S., Kim, H., Park, C. K., McDonald, K., Ha, O. S., Kim, D. L., \& Lee, S. M. (2017). South Korean students' responses to english-medium instruction courses. Social Behavior and Personality, 45(6), 951-965. https://doi.org/10.2224/sbp.6049 


\section{DOI: $\underline{10.51386 / 25815946 / \mathrm{ijsms}-\mathrm{v} 4 \mathrm{i} 5 \mathrm{p} 104}$}

[7] Coyle, D. (2007). Content and language integrated learning: Towards a connected research agenda for CLIL pedagogies. International Journal of Bilingual Education and Bilingualism, 10(5), 543-562. https://doi.org/10.2167/beb459.0

[8] Coyle, D. (2013). Listening to learners: An investigation into "successful learning" across CLIL contexts. International Journal of Bilingual Education and Bilingualism, 16(3), 244-266. https://doi.org/10.1080/13670050.2013.777384

[9] Coyle, D., Hood, P., \& Marsh, D. (2010). Content and Language Integrated Learning (3rd ed.). Cambridge University Press. www.cambridge.org/9780521130219

[10] de Zarobe, Y. R., \& Zenotz, V. (2015). Reading strategies and CLIL: the effect of training in formal instruction. Language Learning Journal, 43(3), 319-333. https://doi.org/10.1080/09571736.2015.1053284

[11] Gregersen, T., \& Horwitz, E. K. (2002). Language Learning and Perfectionism: Anxious and Non-Anxious Language Learners' Reactions to Their Own Oral Performance. The Modern Language Journal, 86(4), 562-570. https://doi.org/10.1111/1540-4781.00161

[12] Horwitz, E. K., Horwitz, M. B., \& Cope, J. (1986). Foreign Language Classroom Anxiety. The Modern Language Journal, 70(2), 125-132. https://doi.org/10.1111/j.1540-4781.1986.tb05256.x

[13] Jensen, C., Denver, L., Mees, I. M., \& Werther, C. (2013). Students' attitudes to lecturers' English in English-medium higher education in Denmark. NJES Nordic Journal of English Studies, 12(1), 87-112. https://doi.org/10.35360/njes.277

[14] Marsh, D., \& Marsh, A. D. (2012). Content and Language Integrated Learning ( CLIL ) A Development Trajectory.

[15] McDougald, J. S. (2015). Teachers' attitudes, perceptions and experiences in CLIL: A look at content and language. Colombian Applied Linguistics Journal, 17(1), 25. https://doi.org/10.14483/udistrital.jour.calj.2015.1.a02

[16] Nguyen, L., \& Thuy, T. (2016). Reconsidering the first steps of CLIL implementation in Vietnam. European Journal of Language Policy, 8(1). https://doi.org/10.3828/ejlp.2016.4

[17] Nguyen, T. B. N. (2019). Content and Language Integrated Learning in Vietnam : Evolution of students 'and teachers 'perceptions in an innovative foreign language learning system. Universite' de Toulouse.

[18] Nguyen, T. L. H. (2016). Building human resources management capacity for university research: The case at four leading Vietnamese universities. Higher Education, 71(2), 231-251. https://doi.org/10.1007/s10734-015-9898-2

[19] Pavón Vázquez, V., \& Ellison, M. (2013). Examining teacher roles and competences in Content and Language Integrated Learning (CLIL). Porta Linguarum, 4(Clil), 67-80.

[20] Tran, T.T.Q, \& Phuong, H.Y. (2019). An investigation into English preparatory programs for EMI learning in higher education institutes in Vietnam. Can Tho University Journal of Science, Vol.11(2)(October), 51. https://doi.org/10.22144/ctu.jen.2019.024

[21] Vu, N. T. T., \& Burns, A. (2014). English as a medium of instruction: Challenges for Vietnamese tertiary lecturers. Journal of Asia TEFL, 11(3), 1-31.

[22] Wolff, D. (2009). Content and language integrated learning. Handbook of Foreign Language Communication and Learning, $545-572$. https://doi.org/10.1080/14790718.2012.665454

[23] Xanthou, M. (2011). The impact of CLIL on L2 vocabulary development and content knowledge. English Teaching, 10(4), 116-126. http://education.waikato.ac.nz/research/files/etpc/files/2011v10n4art7.pdfpp.116-126 